\title{
MOLECULAR CLONING OF THE VITELLOGENIN GENE IN THE HARD-LIPPED BARB (Osteochillus hasseltii C.V) AND PHOTOPERIOD'S EFFECTS ON GENE EXPRESSION
}

\author{
NORMAN ARIE PRAYOGO ${ }^{1,2^{*}}$, ASRUL SAHRI SIREGAR ${ }^{1}$, PURNAMA SUKARDI $^{1}$ \\ AND YASUMASA BESSHO${ }^{3}$ \\ ${ }^{1}$ Faculty of Fisheries and Marine Science, Universitas Jenderal Soedirman, Purwokerto 53122, Indonesia \\ ${ }^{2}$ Center of Marine and Bioscience, Universitas Jenderal Soedirman, Purwokerto 53122, Indonesia \\ ${ }^{3}$ Laboratory of Gene Expression Research, Nara Institute of Science and Technology, Ikoma, Nara 630-0192, Japan
}

Received 21 July 2017 / Accepted 02 November 2017

\begin{abstract}
Photoperiod affects fish reproduction as it regulates activities of the endocrine glands, which produce the hormones needed for geonadal growth and development, gametogenesis, and reproductive cycles. This study aimed to determine the effects of photoperiod on the hard-lipped barb's reproductive performance by exposing the fish to three photoperiod treatments (light hour: L, darks hour: D), namely 14L:10D (control), 8L:16D (short photoperiod) and 18L:6D (long photoperiod), with four aquaria, each containing 9 fish, serving as replicates. The fish were kept under these photoperiods for 8 weeks. Liver activity, the observable variable in the study, was evaluated by measuring vitellogenin gene expression. Normalized data were then subjected to ANOVA, followed by Tukey's range test. The hard-lipped barb's vitellogenin cDNA was found have a 1136 bp sequence and the vitellogenin precursors encoded cDNA comprising 378 amino acids. The vitellogenin gene in each experimental group saw a significant increase on average when exposed to longer photoperiods $(\mathrm{P}<0.05)$, and the highest levels of vitellogenin gene expression occurred under long photoperiods (LP, $18 \mathrm{~h}$ light:6 h dark). These results indicate that longer photoperiods stimulate and improve the hard-lipped barb's reproductive performance.
\end{abstract}

Keywords: amino acid, cDNA, Hard-lipped barb, photoperiods, vitellogenin

\section{INTRODUCTION}

Reproductive activities in fish are regulated by several environmental and physiological factors (Bhattacaraya 1992; Qingbo et al. 2005). Photoperiod exerts it role in reproduction through the brain, which integrates and conveys input from external and internal cues to the pituitary via melatonin (Ekstrom \& Meissl 1997; Cassone 1998; Miranda et al. 2008). Melatonin regulates the synthesis and secretion of the KiSS and GnRH genes (Wang et al. 2013). GnRH controls the secretion of $\mathrm{GtHs}$ (gonadothropins), such as GtH-I and GtH-II (Xiong \& Hew 1991). GtH-I and GtH-II regulate the two main activities of the gonads, i.e., hormone and gamete production (Flack et al. 1994; Bayyari et al. 2004). Ovarian hormones, especially estradiol and progesterone, play

*Corresponding author: norman_s2biologi@yahoo.com important roles in maintaining and promoting gamete production (Biswas et al. 2005). Estradiol regulates vitellogenin secretion from the liver, while vitellogenin plays a role in the vitellogenesis process in ovaria (Sulistyo et al. 1998). In turn, the vitelogenesis process increases oocyte volume until maturation (Yaron 1995; Utoh et al. 2003).

Photoperiod is among the important cues for the spawn timing of many fish species, such as the European sea bass, Dicentrarchus labrax (Rodriguez et al. 2004), Atlantic cod, Gadus morbua L (Skjæraasen et al. 2006), and Chinook salmon or Oncorbynchus tshawytscha (Chyb et al. 1999). The majority of past studies were conducted on temperate-zone fishes in which photoperiods strictly vary between seasons. Studies on the influence of photoperiod on tropical fishes are still limited. Hard-lipped barbs (Osteocbilus basselti C.V)—a tropical fish species-manipulated with longer photoperiods 
18L:6D (18 hours light and 6 hours dark) showed significantly decreased melatonin levels and an increased cGnRH-II gene expression (Prayogo et al. 2012). Altered cGnRH-II and sGnRH levels increased GtH-Ia, GtH-IIa and $\mathrm{GtH}-\mathrm{IIb}$ in the hard-lipped barb.

Hard-lipped barbs are a synchronous batch spawner fish (Prayogo et al. 2016a) capable of spawning several times during the peak of the spawning period. Under suitable environments, this fish is capable of spawning 60 days after its previous spawn. Hard-lipped barbs have been adapted to photoperiods of 12L:12D to 14L:10D. This study was conducted to examine the effects of different photoperiods on the hard-lipped barb's vitellogenin gene expression, to determine photoperiod's effects in enhancing the hard-lipped barb's reproductive performance.

\section{MATERIALS AND METHODS}

\section{Treatment and Sampling of Fish}

A total of 144 sexually mature female hardlipped barbs weighing $100 \mathrm{~g}$ in average were kept at the Laboratory of Fisheries and Marine Science, Jenderal Soedirman University, Central Java, Indonesia. They were induced to spawn using ovaprim at $0.5 \mathrm{ml} / \mathrm{kg}$ their body weights. The spawn day was designated as day zero in the post-spawn period. Post-spawned females were divided into 4 groups, each group consisting of 4 aquariums with 9 fish per $50 \mathrm{~L}$ water.

In this study, three types of photoperiods, namely 6L:18D (SP=Short Photoperiod), 14L:10D (C=control), and 18L:6D (LP=Long Photoperiod). The aquaria were covered with light-proof black poly bags. The light sources, i.e., 25-Watt (Phillips) bulbs, was regulated using automatic timers in 24-hours cycles, and were placed at the top of each aquarium. In the control photoperiod (C) 14L:10D, the light was kept on from 06:00 a.m. until 08:00 p.m.; in the short photoperiod (SP), 8L:16D the light was kept on from 06:00 a.m. until 02:00 p.m.; and in the long photoperiod (LP) 18L:6D the light was kept on from 06:00 a.m. until 12:00 p.m. local time. The fish were reared for 8 weeks at the laboratory of the Aquaculture Department of
Marine and Fisheries, University of Jenderal Soedirman. During the study, the fish were fed on commercial pellet (protein 37\% and fat 10\%) at $3 \%$ of their total body weight daily. The water was siphoned regularly to maintain water quality. Water temperature, dissolved oxygen, $\mathrm{pH}$ and carbon dioxide were monitored at 1-week intervals. At every sampling time, pituitary was collected from 3 fish in each group and was snap-frozen using liquid nitrogen for the study of vitellogenin expression. The expression of vitellogenin genes was evaluated using Real Time PCR, applying primers derived from vitellogenin genes. Real Time PCR was conducted at Jenderal Soedirman University's research laboratory.

\section{Total RNA Isolation and DNAse Treatment}

Total RNA was extracted from whole livers using blue Sepasol R-RNA super-1 reagent, based on the Ethanol-phenol-chloroform extraction method (Prayogo et al. 2016b; Siregar \& Prayogo 2017). The integrity of the RNA was verified in a denaturing agarose gel, stained with ethidium bromide. RNA samples were treated with DNAse free RNAse (Takara). The quality and concentrations of the total RNA were determined using agarose gel electrophoresis and an optical density reading at 260 and $280 \mathrm{~nm}$ (Fig. 1). The RNA was aliquoted in batches and frozen at $-70^{\circ} \mathrm{C}$.

\section{RT-PCR}

The reverse transcription of mRNA samples $(1 \mu \mathrm{l})$ was performed with a cDNA synthesized kit (PrimeScriptTM Reverse Transcriptase, Takara Bio.Inc) using Random 6 mers (sequence pd $(\mathrm{N}) 6,50 \mu \mathrm{M})$ primers and prime script RTase guided with the manufacturer's instructions.

\section{cDNA Amplification}

Degenerate primer pairs of the vitellogenin gene were designed from the cDNA of cyprinidae, such as the Cyprinus carpio and Carrasius auratus. All sequences were aligned using multalin to identify the conserved region in the ORF (Open Reading Frame) region. Primers used to amplify vitellogenin genes were designed using the Primer3 software (Table 1). 
Table 1 Primers used to amplify the vitellogenin genes and their PCR products

\begin{tabular}{clccc}
\hline No. & Name/Primer Code & DNA Sequence (primer) & Tm & PCR Product (bp) \\
\hline 1. & Forward VF (VF) & CGTGGATCHYTGMARTACGAGTT & 62.81 & 1136 bp \\
\hline 2. & Reverse VR (VR) & ATGGTGGCRGCRTCATTGAT & 62.83 & \\
\hline 3. & $\begin{array}{l}\text { Forward VF } \\
\text { Real Time (FRT) }\end{array}$ & GACGCTCCACTCAAGTTTGTTCAG & 61.23 & $150 \mathrm{bp}$ \\
\hline 4. & $\begin{array}{l}\text { Reverse VR } \\
\text { Real Time (RRT) }\end{array}$ & GAGCCCAGATAGCCTCAATGTTC & 62.34 & \\
\hline 5. & Forward Actin (FA) & GAG CTA TGA GCT CCC TGA CGG & 58.3 & $53 \mathrm{bp}$ \\
\hline 6. & Reverse Actin (RA) & AAA CGC TCA TTG CCA ATG GT & 55.6 & \\
\hline
\end{tabular}

Thirty-five cycles of PCR for the hard-lipped barb's vitellogenin were carried out using a thermal cycler (Robocycler, Stratagene) according to the following cycle: $95^{\circ} \mathrm{C}$ for 2 minutes, 35 cycles to $95^{\circ} \mathrm{C}$ for $30 \mathrm{~s}, 55^{\circ} \mathrm{C}$ for 30 $\mathrm{s}, 72^{\circ} \mathrm{C}$ for $60 \mathrm{~s}$, followed by a 5 -min extension at $72^{\circ} \mathrm{C}$. After amplification, the PCR products was electrophoretically separated using 1.5\% agarose gel and stained with ethidium bromide.

\section{Cloning and Sequencing of PCR Products}

PCR products amplified from cDNA samples were separated using agarose gel electrophoresis, and the incised gel was purified using the DNA gel extraction procedure. Desired DNA fragments from the mRNA vitellogenin were subcloned into a $\mathrm{T}$-vector $(10$ ng) (Takara) and ligated with T4 ligase. Plasmids were transfected into E. coli and spread into LB medium. Recombinant positive colonies were screened using ampicillin. Positive colonies were treated using scale plasmid preparation for sequencing. The DNA sequences of these fragments were determined using the Big Dye version 3.1 sequencing method with specific primers (Table 1). Data were automatically collected using the ABI PRISM 3100 Genetic Analyzer (PE Applied Bio-systems).

\section{Sequence Analysis}

Vitellogenin cDNA sequences were checked using BLASTN searches (http://www.ncbi.nlm. nih.gov/BLAST/) performed with default settings on the complete, non-redundant GenBank database of nucleotide sequences.

\section{Phylogenetic Analysis}

For phylogenetic analyses, the hard-lipped barb's vitellogenin cDNA was compared to vitellogenin cDNA sequences from 10 fish species. All sequences were retrieved from the NCBI GenBank. The relationship between the hard-lipped barb's vitellogenin and other teleosts' vitellogenins was generated using CLUSTAL W with a percentage scoring system, while the unrooted tree was generated using TreeView version 1.5.2.

\section{Quantitative Real-Time Analysis}

Primers were designed based on the vitellogenin (submit number: 1995561), and with the Primer 3.0 software. Actin taken from the hard-lipped barb, which was used as endogenous control, was amplified using the following primers:

$\begin{array}{lcc}\text {-actin forward } & \text { primer, } \\ \text { 5'-GAGCTATGAGCTCCCTGACGG-3' } \\ \text {-actin reverse }\end{array}$
5'-AAACGCTCATTGCCAATGGT-3'

and were used to normalize variations in RNA. After optimization, PCR reactions were performed in a $10 \mu \mathrm{l}$ mix reactions containing 2 $\mu \mathrm{l}$ cDNA, $5 \mu \mathrm{l} \mathrm{SYBR}$ mix (Applied Biosystem), $0.3 \mu \mathrm{l}$ forward primer, $0.3 \mu \mathrm{l}$ reverse primer and $2.4 \mu \mathrm{l}$ DDW under the following conditions: $95^{\circ} \mathrm{C}$ for $45 \mathrm{~s}$, $\left(45\right.$ cycles of $95^{\circ} \mathrm{C}$ for $15 \mathrm{~s}$ and $60^{\circ} \mathrm{C}$ for $1 \mathrm{~min}$ ), then $95^{\circ} \mathrm{C}$ for $15 \mathrm{~s}, 60^{\circ} \mathrm{C}$ for 15 $\mathrm{s}$ and $95^{\circ} \mathrm{C}$ for $15 \mathrm{~s}$. The results were analyzed using the standard curve mode, according to the manufacturer's recommendations (Applied Biosystems).

\section{RESULTS AND DISCUSSION}

\section{Identification of Vitellogenin Genes in the Hard-Lipped Barb}

The hard-lipped barb vitellogenin genes were 
successfully amplified from the cDNA. The agarose gel electrophoresis of the vitellogenin cDNA showed a specific band, approximately 1136 bp (submission number: 1995561). Corresponding cDNA sequences were called vitellogenin. cDNA sequences were checked using BLAST, and we found that the identity was not $100 \%$ similar to other vitellogenin genes. The nucleotide sequence identity of the hard-libbed barb's vitellogenin cDNA shared a $77 \%$ similarity with carp (Cyprinus carpio AB331884.1), 78\% with goldfish (Carrasius auratus, FJ524335.1), 78\% with mud crap (Cirrbinus molitorella, GU324313.1), and 75\% with the zebra fish (Danio rerio, NM001122610.3).

\section{Vitellogenin Gene Structure}

Teleosts share the same basic vitellogenin gene structure. Amplification of the hard-lipped barb's vitellogenin showed cDNA fragment contained in the open reading frame of the vitellogenin. The cDNA fragment contained 1136 amino acids and was identified as a mature peptide (Fig. 1).

The hard-lipped barb's vitellogenin coding sequence was found to share great similarities with other teleosts, as can be seen in the distances shown in the phylogenetic tree (Fig. 2, 3 , 4). The greatest differences within the preprohormone were within the GAP coding sequences. The striking contrast between the conservation of the vitellogenin coding sequence and the lack thereof in the GAP coding sequence is evidence of differential selective pressure within the gene. This is evident in cases where the identities of and similarities between vitellogenin and GAP coding sequences were compared for the mRNAs of different vitellogenin genes within a species.

\section{Phylogenetic Analyses}

Phylogenetic analyses were performed to establish an evolutionary context for vitellogenin genes. Genetic distances (measured as substitutions per site) showed moderate low values, and the topology was well supported by strong bootstrap values. As expected, vitellogenin in the hard-lipped barb was included within a sub-cluster of the carp (Cyprinus carpio) and goldfish (Carrasius auratus) with high bootstrap values (Fig. 2).

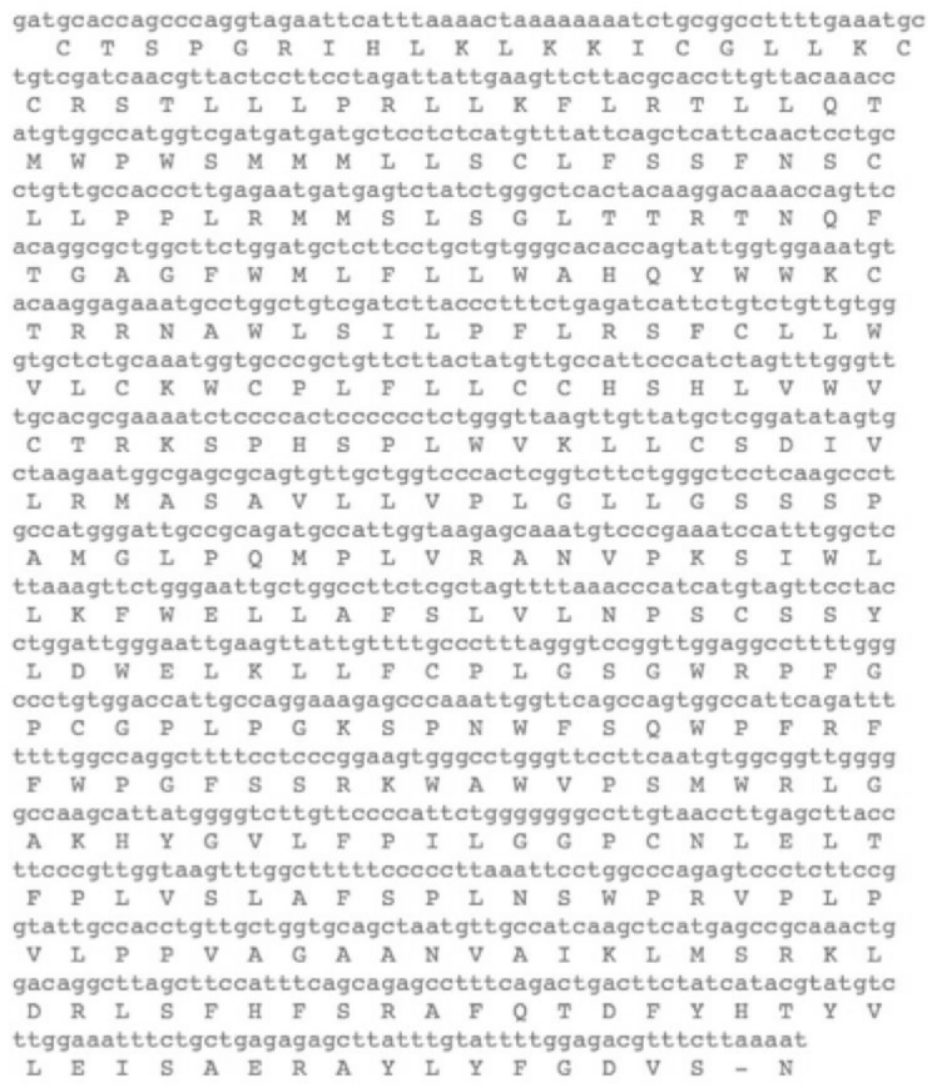

Figure 1 The hard-lipped barb's vitellogenin nucleotide and amino acid sequence 


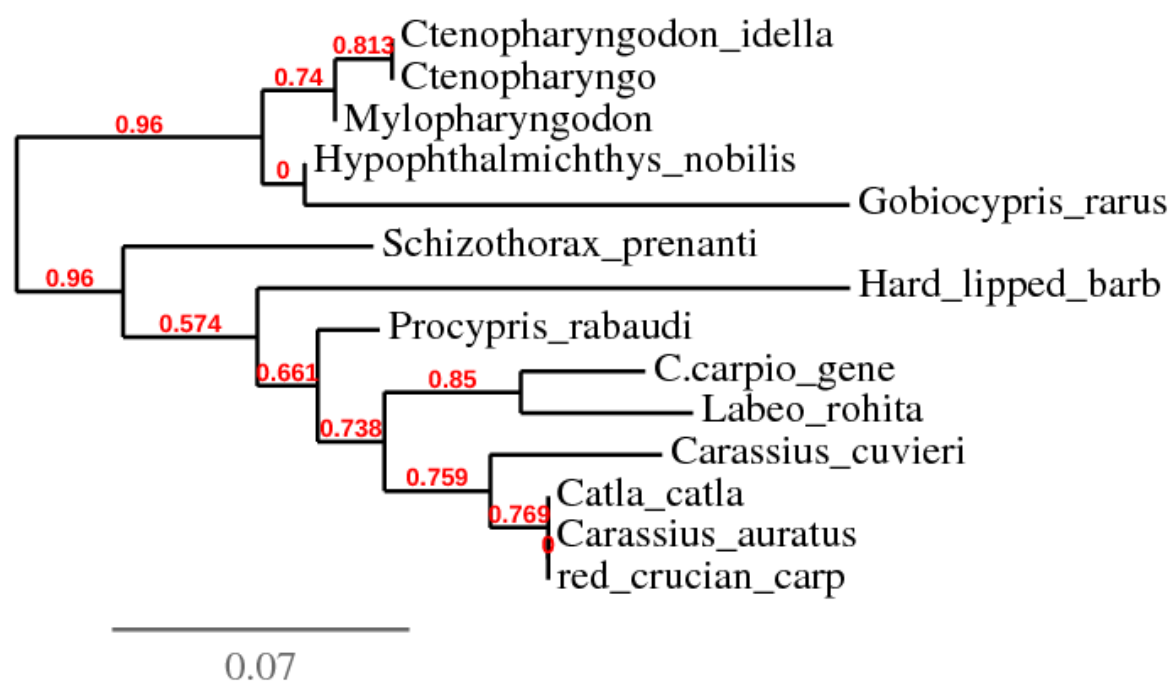

Figure 2 The phylogenetic relationships between precursors, derived from known vitellogenin nucleotide coding sequences. These relationships were generated using CLUSTAL W and the unrooted tree was generated using TreeView version 1.5.2. The scale bar represents the estimated evolutionary distance of 0.1 amino acid substitutions per site.

This paper reports for the first time the cloning of vitellogenin genes from the hardlibbed barb's pituitary tissues. Comparisons between the fish's vitellogenin gene structure and the previously reported gene structures of other fish species point to high conservation. The nucleotide sequence of vitellogenin mRNA also shared great similarities to other vitellogenin variants, with BLAST results showing a 78\% similarity to carp (Cyprinus carpio AB331884.1), $78 \%$ to goldfish (Carrasius auratus, FJ524335.1),
$78 \%$ to mud crap (Cirrbinus molitorella, GU324313.1), and $75 \%$ to the zebra fish (Danio rerio, NM001122610.3) (Fig. 3).

This result points to great similarity between the hard-lipped barb's vitellogenin genes and those of carp and goldfish. The highest similarity was identified between the vitellogenins of the hard-lipped barb and the Carrasius auratus (78\%). Based on this result, we propose that the hard lipped-barb has two forms of vitellogenin, similar to goldfish (Fig. 3).

\begin{tabular}{|c|c|c|c|c|c|c|}
\hline \multicolumn{7}{|l|}{ î Alignments $=$ in Download $\times$ GenBank Graphics Distance tree of resullts } \\
\hline Description & $\begin{array}{l}\text { Max } \\
\text { score }\end{array}$ & $\begin{array}{l}\text { Total } \\
\text { score }\end{array}$ & $\begin{array}{l}\text { Query } \\
\text { cover }\end{array}$ & $\begin{array}{c}E \\
\text { value }\end{array}$ & Ident & Accession \\
\hline Cirmhinus molitorella vitellogenin B1 N(ta-B1) mRNA, complete cods & 651 & 651 & $87 \%$ & 0.0 & $79 \%$ & GU324313.1 \\
\hline PREDICTED: Sinocyclocheilus grahami vitellogenin-like (LOC107563524), transcript variant X2, mRNA & 617 & 617 & $87 \%$ & $1 e-172$ & $78 \%$ & XM 016248425.1 \\
\hline PREDICTED: Sinocyclocheilus grahami vitellogenin-like (LOC107563524), transcript variant X1, mRNA & 617 & 617 & $87 \%$ & $1 e-172$ & $78 \%$ & $\underline{X M} 016248424.1$ \\
\hline Detroleuciscus estahani vitellogenin mRNA, complete cds & 617 & 617 & $87 \%$ & $1 e-172$ & $78 \%$ & KF766534.1 \\
\hline Carassius auratus ssp. 'Pengze' vitellogenin B variant 2 mRNA, partial cds & 601 & 601 & $89 \%$ & $1 e-167$ & $78 \%$ & KF 373230.1 \\
\hline$\square$ Carassius auratus vitellogenin mRNA, partial ods & 595 & 595 & $89 \%$ & $7 e-166$ & $78 \%$ & E.J524335.1 \\
\hline$D$ PREDICTED: Sinocyclocheilus minocerous vitellogenin-like (LOC107715697), mRNA & 593 & 593 & $87 \%$ & 2e-165 & $78 \%$ & XM 016521872.1 \\
\hline PREDICTED: Sinocyclocheilus anshuiensis vitellogenin-like (LOC107664867), mRNA & 590 & 590 & $87 \%$ & $3 e-164$ & $78 \%$ & XM 016455551.1 \\
\hline$\square$ PREDICTED: Sinocyclocheilus anshuiensis vitellogenin-like (LOC107664873), mRNA & 579 & 579 & $87 \%$ & $7 e-161$ & $77 \%$ & XM 016455561.1 \\
\hline - Gobiocypris rarus vitellogenin A01-like (vigAo1) mRNA, complete sequence & 573 & 573 & $87 \%$ & 3e-159 & $77 \%$ & EU623080.1 \\
\hline$\square$ Pimephales promelas vitellogenin precursor (Ntg) mRNA, complete cds & 573 & 573 & $86 \%$ & 3e-159 & $78 \%$ & AF130354.1 \\
\hline DREDICTED: Sinocyclocheilus anshuiensis vitellogenin-1ike (LOC107655402), transcript variant X3, mRNA & 562 & 562 & $87 \%$ & $7 e-156$ & $77 \%$ & XM 016442878.1 \\
\hline DREDICTED: Sinocyclocheilus anshuiensis vitellogenin-like (LOC107655402), transctipt variant X2, mRNA & 562 & 562 & $87 \%$ & $7 e-156$ & $77 \%$ & XM 016442877.1 \\
\hline PREDICTED: Sinocyclocheilus anshuiensis vitellogenin-like (LOC107655402), transcript variant X1, mRNA & 562 & 562 & $87 \%$ & $7 e-156$ & $77 \%$ & XM 016442876.1 \\
\hline DREDICTED: Sinocyclocheilus grahami vitellogenin-like (LOC107570369), mRNA & 562 & 562 & $87 \%$ & $7 e-156$ & $77 \%$ & $\underline{X M} 016256599.1$ \\
\hline Dhinichthys cataractae vitellogenin mRNA, partial cods & 558 & 558 & $86 \%$ & $9 e-155$ & $77 \%$ & EF202607.1 \\
\hline DREDICTED: Sinocyclocheilus grahami vitellogenin-like (LOC107570371), mRNA & 556 & 556 & $87 \%$ & 3e-154 & $77 \%$ & $\underline{X M} 016256602.1$ \\
\hline Cyprinus carpio vg-B1 mRNA for vitellogenin B1, complete cds & 556 & 556 & $87 \%$ & 3e-154 & $77 \%$ & AB331884.1 \\
\hline Carassius auratus ssp. 'Pengze' vitellogenin B variant $1 \mathrm{mRNA}$, complete cds & 553 & 553 & $86 \%$ & $4 e-153$ & $77 \%$ & KF 373229.1 \\
\hline
\end{tabular}

Figure 3 Comparisons between the hard-lipped barb's vitellogenin nucleotide and other cyprinids 


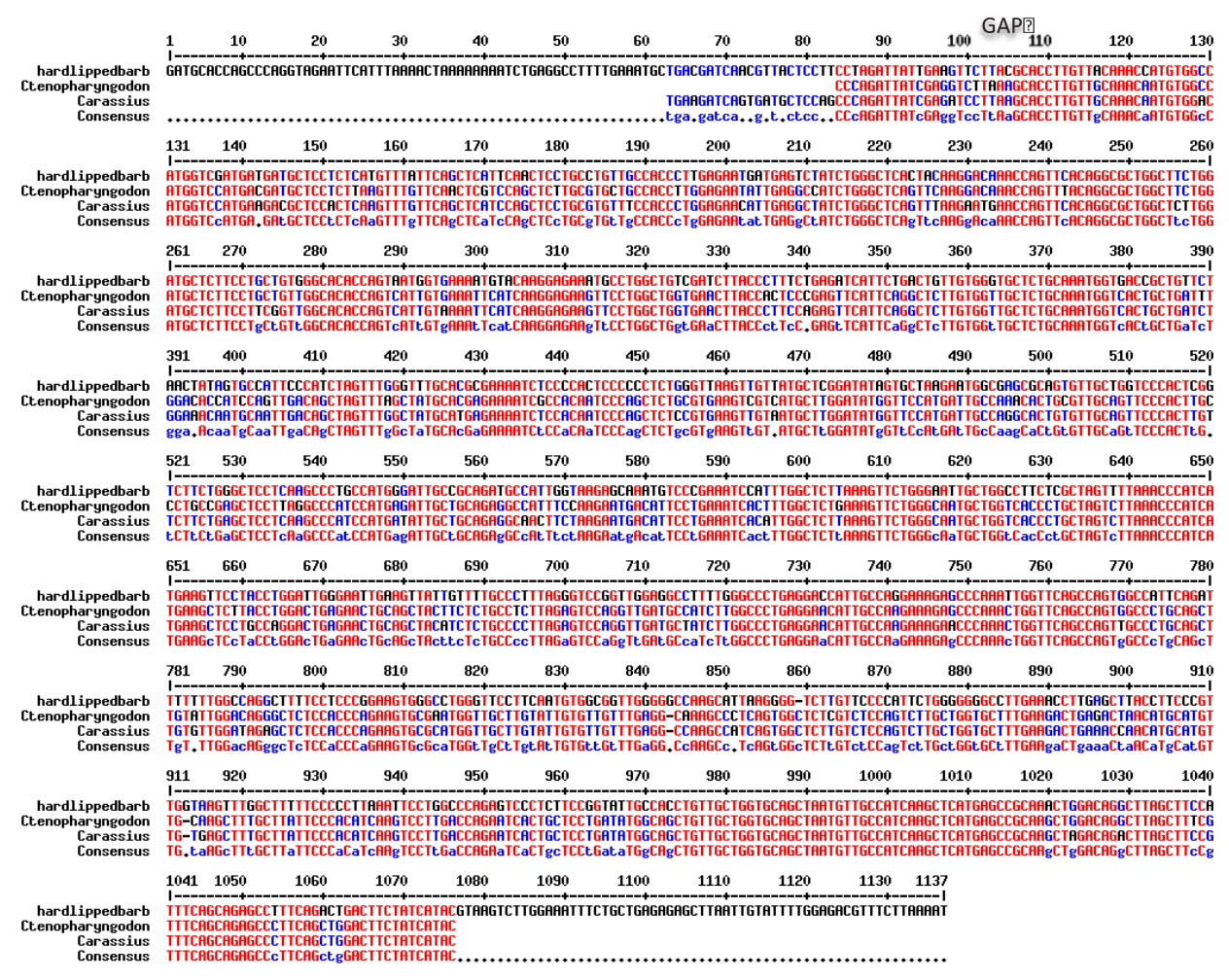

Figure 4 Multalin vitellogenin sequencing of the hard-lipped barb and goldfish

The mRNA-encoded vitellogenin precursor contained 378 amino acid residues. The vitellogenin precursor was composed of mature peptides (Fig. 1). The mRNA-encoded amino acid sequences of the hard-lipped barb's precursors were compared to several previously identified vitellogenin precursors (Fig. 3), such as the precursors of rohu (Labeo rohita), goldfish (Carassius auratus), carp (Cyprinus carpio), grass carp (Ctenopharyngodon idella), rainbow trout (Oncorbyncus mykiss), and rock carp (Procypris rabaudi). Results showed that the amino acids of vitellogenin precursors within the Cyprinoidea suborder were $65-77 \%$ homologous. However, the alignment showed that the hard-lipped barb's mature vitellogenin peptides had different amino acids from other teleosts such as rainbow trout and grass carp, namely, 41(R) and $43(\mathrm{~N})$. Variations in vitellogenin GAP (Gene Associated Peptides) indicated that GAP function may differ from species to species.

This study provides new evolutionary information on this fish family's vitellogenin genes, which are found in the brain. Vitellogenins in the hard-lipped barb were grouped with other teleosts in the phylogenetic tree, suggesting a common ancestor. Phylogenetic analysis showed that vitellogenins can be separated into 2 major groups. Sub-group I contains vitellogenins from the black carp to Rutilus rutilus, and Sub-group II from goldfish to carp (Fig. 4).

Mature peptide is a minimal structural requirement for delineated vitellogenin activity (Hiramatsu et al. 2002). The hard-lipped barb's mature vitellogenin peptides are similar to those of carp and are assumed to have the same functions (Kang et al. 2007). Results from comparisons of vitellogenin precursors sequences of different vertebrates showed that mature vitellogenins are highly conserved (Fig. 4). A mature peptide is a peptide chain that codes the sequence of the mature or final peptide or protein product following posttranslational modification-which means that vitellogenins have been conserved during the process of evolution. The hard-lipped barb's vitellogenin genes were shown to be similar to those of goldfish. Based on this result, it's possible that the hard-lipped barb's vitellogenin has multiple vitellogenin genes (Kang et al. 2007). 


\section{Expression of Vitellogenin mRNA under Manipulated Photoperiods}

In the female hard-lipped barb, relative vitellogenin $\mathrm{mRNA}$ expression levels during the eight-week period were 1-4.35 (Fig. 5). The highest vitellogenin mRNA expression (4.35) was observed for 8 weeks in the LP group, found to be significantly different $(p<0.05)$. mRNA expression in the 18L:6D group increased during post-spawn periods $(p<0.05)$. Vitellogenin mRNA expression for other photoperiod treatments with 2 -week and 4-week durations were not significantly different ( $>>0.05)$, but the 6-week and 8-week photoperiods (LP) had higher vitellogenin gene expression than the short photoperiod (SP) and control $(\mathrm{C})$ groups $(\mathrm{p}<0.05)$.

In this study, changes in vitellogenin gene expression levels in the hard-lipped barb were analyzed to characterize the role of neuropeptides in controlling reproduction under photoperiod manipulation. This study confirms previous fisheries laboratory results, showing increased vitellogenin gene levels in the hardlipped barb during photoperiod manipulation. In addition, we report, for the first time, changes in vitellogenin gene expression levels in correlation with photoperiod manipulation. Although we're aware that mRNA levels do not always match protein levels and/or the physiological effects of protein products, the regulation of mRNA levels provides some indication of the activity of a particular peptide neuronal system.

This study showed an increase in vitellogenin levels equivalent to the increase in the photoperiod's duration. This proves that photoperiod exerts its role in reproduction through the hipotamaus-pituitary-gonad (Miranda et al. 2008), which integrates and conveys input from external and internal cues to the pituitary organs (Cassone 1998; Bromage et al. 2001). Photoperiod regulates melatonin production and melatonin mediated cyclical regulation of the GnRH mRNA expression involving protein kinase $\mathrm{c}$ and the extracellular signal-regulated kinase 1 and 2 pathways. Melatonin acts through membrane receptors to trigger protein kinase $\mathrm{C}$ pathway, and 12-Otetradecanoyl phorbol-13-acetate (TPA), a modulator of this pathway, has been shown to suppress $\mathrm{GnRH}$ gene expression through the promoter (Qingbo et al. 2005). GnRH binds to $\mathrm{GnRH}$ receptor and active $G$ protein mediates phosphorylation to protein kinase $\mathrm{C}$ and synthesizes Gonadotrophin (GtH-I and GtH-II) (Chyb et al. 1999; Minniti et al. 2007). GtH-II is secreted into blood vessels to theca-cell receptors, for activating $G$ protein and adenylate cyclase to phosphorylate cAMP, and activating

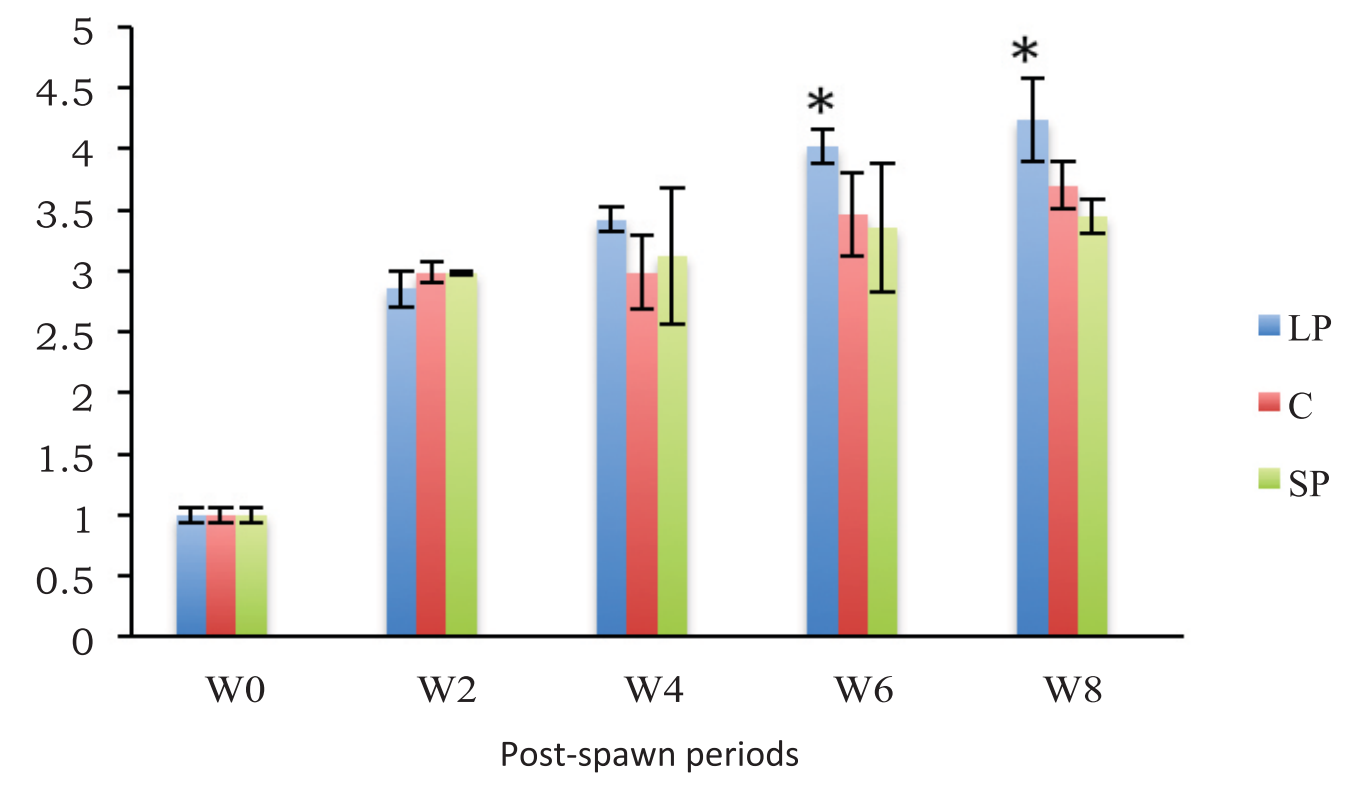

Figure 5 The vitellogenin gene expression of hard-lipped barbs kept under different photoperiods for 8 weeks Note: LP=18L:6D, C=14L:10D, SP=6L:8D) ('significantly different) 
StAR protein to produce cholesterol. FSH and LH receptor activity in gonad females promote the production of estradiol-17h (E2), the main sex steroid. E2 functions primarily to induce vitellogenin or yolk protein secretion by the liver. Generally, estradiols increased during the most active vitellogenesis period and returns to basal levels before ovulation. Embryos are dependent on egg-yolk for their nutritional requirements. The process of yolk deposition during vitellogenesis in oocytes is a seasonal, or cyclic, phenomenon.

\section{CONCLUSION}

In summary, the present work has, for the first time, reported the vitellogenin sequence of the hard-lipped barb. The phylogenetic results presented in this work support the idea that vitellogenin genes share the same basic structure, meaning the hard-lipped barb's vitellogenin has been highly conserved. We found that photoperiod affects the regulation of vitellogenin gene expression in the hard-lipped barb, with longer photoperiods increasing vitellogenin gene expression via the HPG axis.

\section{ACKNOWLEGMENTS}

This project was funded by DIKTI (International Research Collaboration 2016). We would also like to thank Hanifa Kumalasari and Hartoyo Notonegoro for their assistance with Real Time PCR.

\section{REFERENCES}

Bayyari MJ, Rodriguez I, Zanuy S, Madrid JA, SanchezVazquez FJ, Kagawa H, ... Carrillo M. 2004. Effect of photoperiod manipulation on the daily rhythms of melatonin and reproductive hormones in caged european sea bass (Dicentrarchus labrax). Gen Comp Endocrinol 136:72-81.

Bhattacaraya S. 1992. Endocrin control and fish reproduction. Curr Sci 63(3):135-9.

Biswas SK, Morita T, Yoshizaki G, Maita M, Takeuchi T. 2005. Control of reproduction in nile tilapia Oreochromis niloticus (1.) by photoperiod manipulation. Aquaculture 243:229-39.
Bromage NR, Porter MJR, Randall CF. 2001. The environmental regulation of maturation in farmed finfish with special reference to the role of photoperiod and melatonin. Aquaculture 197:6398.

Cassone VM. 1998. Melatonin_S role in vertebrate circadian rhythms. Chronobiol Int 15:457-73.

Chyb J, Mikolajczyk T, Breton B. 1999. Post-ovulatory secretion of pituitary gonadotropins gth $\mathrm{i}$ and gth ii in the rainbow trout (Oncorbynchus mykiss): Regulation by steroids and possible role of nonsteroidal gonadal factors. J Endocrinol 63(1):87-97.

Ekstrom P, Meissl H. 1997. The pineal organ of teleost fishes. Rev Fish Biol Fisher 7:199-284.

Flack MR, Froehlich J, Bennet AP. 1994. Site-directed mutagenesis defines the individual roles of the glycosylation sites on follicle stimulating hormone. J Biol Chem 269:14015-20.

Hiramatsu N, Matsubara T, Hara A, Donato DM, Hiramatsu K, Denslow ND, Sullivan CV. 2002. Identification, purification and classification of multiple forms of vitellogenin from white perch (Morone americana). Fish Physiol Biochem 26:35570.

Kang BJ, Jung JH, Lee JM, Lim SG, Saito H, Kim MH, ... Han CH. 2007. Structural and expression analyses of two vitellogenin genes in the carp, Cyprinus carpio. Comp Biochem Physiol B 148:445-53.

Minniti F, Maisano M, Giannito A, Mauceri A, Sasuolo F. 2007. GtH-I and GtT-II in the pituitary gland of swordfish (Xiphias gladius L.). Ital J Zool 76:269-78.

Miranda LA, Strussmann CA, Somoza GM. 2008. Effects of light and temperature conditions on the expression of gnrh and gth genes and levels of plasma steroids in Odontesthes bonariensis females. Fish Physiol Biochem 35:101-8.

Prayogo NA, Wijayanti GE, Murwantoko, Kawaichi M, Astuti P. 2012. Effect of photoperiods on melatonin levels, estradiols level and the expression of cgnrh-ii and sgnrh genes, in hardlipped barb (Osteochilus hasselti C.V.). Glob Vet 8(6):591-7.

Prayogo NA, WIjayanti GE, Sulistyo I, Sukardi P. 2016a. Cloning and expression cgnrh-ii and sgnrh genes in hard-lipped barb (Osteochilus hasselti C.V.). Biodiversitas 17(29):523-30.

Prayogo NA, Siregar, Sukardi P. 2016b. The disruptive effect mercurychloride $(\mathrm{HgCl})$ on gene expression of cgnrh-ii, sgnrh, and estradiol level in silver sharkminnow (Osteochillus hasseltii C.V.). Turk J Fish Aquat Sci 16(2):1003-9.

Qingbo T, Mazur M, Mellon PL. 2005. The protein kinase c pathway acts through multiple transcription factors to repress gonadotropin-releasing hormone gene expression in hypothalamic gt1-7 neuronal cells. Molecul Endocrinol 19(11):2769-79. 
Rodriguez I, Carrillo M, Sorbera I, Zohar Y, Zanuy S. 2004. Effects of photoperiod on pituitary levels of three forms of gnrh and reproductive hormones in the male european sea bass (Dicentrarchus labrax L.) during testicular differentiation and first testicular recrudescence. Gen Comp Endocrinol 136:37-48.

Siregar AS, Prayogo NA. 2017. The disruptive effect of mercury chloride $(\mathrm{HgCl})$ on gene expression of gonadotrophin hormones and testosterone level in male silver sharkminnow (Osteochilus hasseltii C.V.) (Teleostei: Cyprinidae). European Zoological Journal. 84 (1):434-443.

Skjæraasen JE, Nilsen T, Kjesbu OS. 2006. Timing and determination of potential fecundity in atlantic cod (Gadus morbua). Fish Aquat Sci 63:310-20.

Sulistyo I, Fontaine P, Rinchard J, Gardeur JN, Migaud H, Capdeville B, Kestemont P. 1998. Reproductive cycle and plasma levels of sex steroid in female eurasian perch, Perca fluviatalis. Aquat Living Resour 11(2):101-10.

Utoh T, Horie NA, Okamura Y, Yamada S, Tanaka N, Mikawa A, ... Oka HP. 2003. Oogenesis in the common japanese conger Conger myriaster. Fisheries Sci 69:181-8.

Wang Q, Sham KW, Ogawa S, Li S, Parhar IS, Cheng $\mathrm{CH}, \ldots$ Lin H. 2013. Regulation of the two kiss promoters in goldfish (Carassius auratus) by estrogen via different alpha pathway. Mol Cell Endocrinol 375(1-2):130-9.

Xiong F, Hew CL. 1991. Chinook salmon gonadotropin ii B-subunit gene encodes multiple messenger ribonucleic acids. Can J Zool 69:2572-8.

Yaron Z. 1995. Endocrine control of gametogenesis and spawning induction in the carp. Aquaculture 129:49-73. 